\title{
Allocation of the Number of Employees Based on Workload at PT Asuransi Central Asia Medan Branch
}

\author{
Suvana Aninda ${ }^{1}$, Harmein Nasution ${ }^{2}$, Linda Trimurni Maas ${ }^{2}$ \\ ${ }^{1,2}$ Master of Management Study Program on Postgraduate School at University of Sumatera Utara
}

Corresponding Author: Suvana Aninda

\begin{abstract}
Human resources are individuals who work as the cogs of a company and can produce ideas that are useful for the company. A company must have a department which in carrying out its duties functions to regulate planning in Human Resources and in carrying out the department concerned will calculate the number of employees who will then be given authority or responsibility for their work. Productivity and work efficiency can be disrupted if there is an employee workload. Employee workload can occur when doing tasks that exceed the ability of employees. At PT Asuransi Central Asia there is an imbalance of work in some divisions and causes delays in completing work. In addition, the distribution of employees in each work unit, there are still those who do not refer to the workload and there are also employees who do not use their productive time as well as possible. The purpose of this study is to analyze the working time of employees by using the Work Sampling method and also to analyze the amount employee needs based on workload measurement with the Full Time Equivalent method. The results of this study indicate that the effective working day for a year is 226 days and the effective working time is 1,360 hours for five working days per week. Through the Work Sampling method, it is known that the total time for productive activities is $78 \%$, unproductive activities are $11 \%$ and personal activities are $11 \%$ with a $30 \%$ allowance. Based on the results of measuring the workload with the Full Time Equivalent method, it can be seen that there are 16 employees with an under load workload, an in load workload of 13 employees and an employee with an overloaded workload
\end{abstract}

of 8 employees. Therefore, the company can take several steps to optimize its employees, namely by transferring tasks from overloaded employees to under loaded employees in the same division, companies can also increase working time with overtime wages without having to add 5 employees to save company costs, companies can also conduct employee transfers, provide training and education to improve employee skills and knowledge, and pay attention to the employee's work system.

Keywords: Employee Needs, Workload, Work Sampling, Full Time Equivalent

\section{BACKGROUND}

Manpower planning is the process of estimating the quality and quantity of human resources needed by the company in the future and also implementing the efforts that must be made to meet these needs. The purpose of workforce planning is to maintain or obtain the number and quality of human resources needed, optimize the human resources owned by the company and anticipate problems that occur (Pranoto and Retnowati, 2019). In companies, both products and services must pay attention to the performance of their employees and also the number of employees needed. The goal is to increase efficiency and find out the existing workload. The productivity and efficiency of the company can be seen from the output produced by its employees in meeting the company's targets. Productivity and work efficiency can be disrupted if there is an employee workload. Workload 
usually occurs when there is a demand that exceeds the capacity of the employee and there are high expectations in a short time (Omar et al, 2020).

Workload is also defined as a situation where employees are faced with tasks that must be completed at a certain time (Munandar in Widiastuti et al, 2019). Workload is also the number of activities that must be completed by a person/individual or group of individuals during a certain period of time in normal/standard working hours (Herrianto in Widiastuti et al, 2019). The workload of employees charged to employees can be divided into three, namely workloads that are too high (over capacity), standard workloads and low workloads (under capacity) (Hartono and Kusuma, 2020). If the workload is too heavy it will cause work inefficiency but if it is excessive, it will cause an excess of manpower.

In managing the company, there are usually several phenomena in the duties and functions, namely the company believes its employees can work according to the given target. In addition, there is also a workload where employees do more work than they should. Therefore, optimizing employee working time can be done by conducting job analysis and also workload analysis to determine employee needs.

At PT Asuransi Central Asia, some divisions with only a few employees do quite a lot of work and some divisions with many employees have a small scope of work so that it causes an imbalance of work in some divisions and causes delays in completing work. The delay in completing the work can be seen from the results of observations where the finance department also provides limited stamp duty for the underwriting section, for example, stamp duty is sometimes only given 50 but the number of policies that must be signed is approximately 200 policies and requires 200 stamps, then the underwriting department must inform back to the finance department and waiting for the stamp duty purchase process to be given to the underwriting department so that there can be delays in signing the policy.

The results of the survey stated that the work target achieved was too high, as many as 5 people aged over 35 years stated this but employees with an age range between 18-34 stated that the work target achieved was not too high. From the results of the pre-survey, it is also known that employees who have less scope of work feel that their workload can still be increased but some employees feel that the workload cannot be increased because the employee has an excessive workload or overload.

At this point the tasks given are sometimes sudden and must be done in a short time and I do a lot of work every day and must be completed immediately so that the workload on some employees increases. At the point I was satisfied with the scope of work given, the employee answered yes because in terms of experience and their working period of more than 5 years made them understand what had to be done and it was in accordance with the employee's skills. The conclusion from the observations above is that the workload given is not evenly distributed because employees in some divisions feel overloaded with work but employees in some divisions feel that their workload can still be increased. The division that felt overloaded stated that this was due to the work being done in duplicate, causing delays in completing the work.

Based on this explanation, to strengthen the statement above, the researcher also conducted interviews with the HRD \& GA section of the company and the results of the interviews stated that the distribution of employees in each work unit, there were still some who did not refer to the workload where currently there were employees who were not in accordance with the requirements competence. According to sources, there are also employees who do not use their productive time as well as possible, there are also double jobs in a division, and there are also jobs that are hampered due to several obstacles, some are 
working less than optimally in achieving their work targets, therefore it is necessary to analyze workload in manpower planning.

Supervisors are assessed from managerial skills, professional skills, personality and work attendance of their employees, while for staff the aspects that are assessed are professional skills, personality and employee attendance. From this assessment, it is known that there is an employee's workload. The workload for each employee can be different because each employee certainly has a job that routinely must be done every day and incidental daily work. If the work changes automatically the workload will increase or decrease. Therefore, the researcher wants to know more clearly about the description of the use of working time and the number of employee needs based on the measurement of the employee's workload.

Based on the description above, it can be concluded that there is an imbalance in work and work delays so that researchers try to formulate work balance and measure work time to find out how much labor is needed by each division by using workload analysis.

\section{Human Resource Planning}

Retnowati (2019) stated that human resource planning is really needed to find out the condition of each employee in a certain position and to anticipate needs in accordance with the demands of the organization. The output of the workload analysis is the volume of workload that must be carried out by an organization or work unit. The workload must be converted into units of the number of human resources needed to complete the workload.

Nasution (2005) states that the right dimensions in HR planning are the right amount, the right quality, the right composition and the right time. HR planning also goes through several stages:

1. Availability analysis of human resources is carried out to determine current and future conditions related to the composition of the workforce owned by the company in terms of quantity, quality, age and potential;

2. HR Demand Analysis is done by forecasting HR needs at a certain time period and related to company strategy;

3. Aspects of the Quality and Quantity Gap;

\section{Workload}

Workload occurs when there is a demand that exceeds the capacity of the employee and there are high expectations in a short time (Omar et al, 2020). Workload is also defined as a situation where employees are faced with tasks that must be completed at a certain time (Munandar in Widiastuti et al, 2019). Workload basically comes from the requirements of a job that exceeds human limits, where the work done is countless and the need to complete the work within a certain period of time by workers (Morrill, Hines, Mahmood, and Córdova in Omar et al, 2020). Workload analysis is the process of collecting, calculating and determining the volume of business or workload to complete work in a particular division. Business volume can be expressed in several measures, including: man hour, man week, man month or number of workers.

\section{Employee Needs Analysis}

Calculation of employee needs is carried out to meet the needs of employees as planned in terms of quantity, time and quality. Employee needs are obtained by determining the average ability standard of achieving time in completing their tasks and the number of tasks loads in a year usually the workload for each main task can be known. Determination of the number of employees can be done by adding the number of employees who have been calculated with a certain allowance.

Kurniawan (2020) in his research entitled Analysis of PT XYZ Indonesia's Employee Workload in the Insulation section using the Full Time Equivalent Method stated the purpose of this study was to equalize the workload of operators and 
determine the optimal number of workers. Researchers used the Full Time Equivalent method. After calculating with this method, the actual condition at PT XYZ Indonesia has 16 operators in the insulation section, with the average workload value obtained is 0.34 the workload value is classified as a low workload (underload). from the researchers, namely 9 operators work on the insulation section with the average workload value obtained is 1.06 the workload value is classified as a normal workload (fit). So that it is easy to supervise the operators due to a reduction or transfer of 7 operators.

Chizbiyah, Purnama, Witchayo, Utami and Chalidyanto (2020) in their research entitled The Analysis of Workload of Outpatient Officers Based on Health Workload Analysis Method stated that the results of this study indicate that unproductive activities are found in the file receiving staff and productive activities in coding, costing, supervisory staff and outpatient evaluation staff.

\section{Conceptual Framework}

This research was conducted by induction through observation and interviews, it was found that there were frequent delays in the completion of work in each part of the organization. The theoretical approach used to solve the problem is ergonomics theory, namely by analyzing the workload of each part of the organization, establishing work elements, measuring work completion standards by conducting job analysis first.

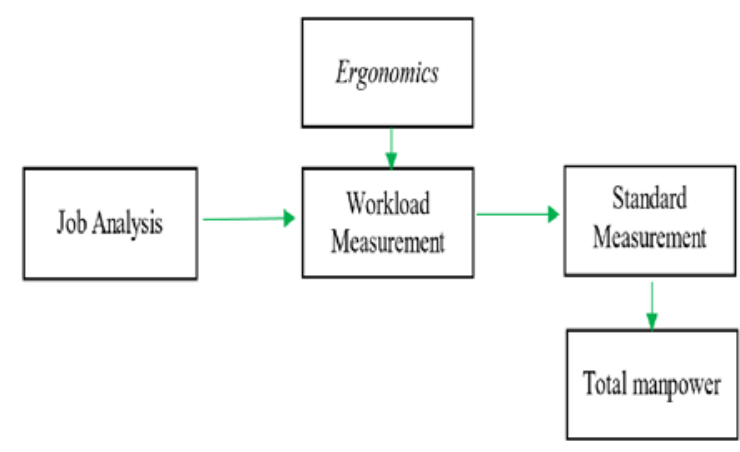

Figure 1. Conceptual Framework

\section{RESEARCH METHOD}

This research is a descriptive research with a quantitative approach. This study investigates the activities of employees obtained from observations and interviews but does not test the research hypothesis. The population in this study were all employees who worked at PT Asuransi Central Asia Medan branch as many as 37 people. In this study, the sampling technique used is non-probability sampling using saturated sampling, namely the determination of the sample when all members of the population are used as a sample, namely 37 people.

Data Analysis Method was carried out on the relationship between work productive time and workload and the allocation of employees in each section, and compared the actual conditions with the results of the study. In this study, PT Asuransi Central Asia Medan branch is the place studied by researchers. In this company, there is an imbalance in work and work delays so that researchers conduct a workload analysis to find out how much manpower is needed by each division for future HR planning. So, the researchers conducted a data analysis that began with examining the known data from the work sampling sheet.

The working time of employees at PT Asuransi Central Asia Medan branch is grouped into three, namely productive working time, unproductive working time and personal working time. The grouping of working time is to find out what percentage of work time is used by employees whether they are doing productive, personal or unproductive activities, therefore the description of the use of working time can be explained. The next step is to input data on the average frequency of the main tasks of each employee and the average ability standard of completion time for each employee's task into the calculation of employee needs based on their workload which will later become the basis for calculating the number of employee needs. 


\section{RESULT AND DISCUSSION \\ Workload Analysis}

Workload based on Full Time Equivalent

The total index value at Full Time Equivalent consists of three groups, namely under load (FTE Index value ranges from 00.99), normal (FTE Index value ranges from 1-1.28) and overload (FTE Index value is greater than 1.28).

Table 1. Calculation Results with the FTE Method

\begin{tabular}{|c|c|c|c|c|c|}
\hline No & Division & Workload & $\begin{array}{l}\text { Bffective Working } \\
\text { Time }\end{array}$ & FTE & Information \\
\hline \multirow[t]{2}{*}{ P1 } & $H R D \& G A$ & 1.448 & 1.360 & 1.06 & In load \\
\hline & Total & 1.448 & 1.360 & 1.06 & In load \\
\hline PI & Underwriting & 1.320 & 1.360 & 0,97 & Under load \\
\hline P2 & Underwriting & 1.365 & 1.360 & 1,00 & In load \\
\hline P3 & Underwriting & 1.191 & 1.360 & 0,88 & Under load \\
\hline P4 & Underwriting & 1.365 & 1.360 & 1,00 & In load \\
\hline P5 & Underwriting & 1.314 & 1.360 & 0,97 & Under load \\
\hline P6 & Underwriting & 1.331 & 1.360 & 0,98 & Under load \\
\hline P7 & Underwriting & 1.412 & 1.360 & 1,04 & In load \\
\hline \multirow[t]{2}{*}{ P8 } & Underwriting & 1.865 & 1.360 & 1,37 & Overload \\
\hline & Total & 11.163 & 1.360 & 1.03 & In load \\
\hline Pl & Claim & 1.873 & 1.360 & 1.38 & Overload \\
\hline P2 & Claim & 742 & 1.360 & 0.54 & Under load \\
\hline P3 & Claim & 954 & 1.360 & 0.70 & Under load \\
\hline P4 & Claim & 1.018 & 1.360 & 0.75 & Under load \\
\hline P5 & Claim & 1.290 & 1.360 & 0.95 & Under load \\
\hline P6 & Claim & 1.422 & 1.360 & 1.05 & In load \\
\hline P7 & Claim & 1.990 & 1.360 & 1.46 & Overload \\
\hline \multirow[t]{2}{*}{ P8 } & Claim & 1.999 & 1.360 & 1.47 & Overload \\
\hline & Total & 11.260 & 1.360 & 1.04 & In load \\
\hline P1 & Finance & 1.420 & 1.360 & 1.04 & In load \\
\hline P2 & Finance & 738 & 1.360 & 0.54 & Under load \\
\hline P3 & Finance & 1.620 & 1.360 & 1.19 & In load \\
\hline \multirow[t]{2}{*}{ P4 } & Finance & 1.072 & 1.360 & 0.79 & Under load \\
\hline & Total & 4.850 & 1.360 & 0.89 & Under load \\
\hline Pl & Marketing & 1.260 & 1.360 & 0,93 & Under load \\
\hline P2 & Marketing & 1.024 & 1.360 & 0,75 & Under load \\
\hline P3 & Marketing & 1.007 & 1.360 & 0,74 & Under load \\
\hline P4 & Marketing & 1.587 & 1.360 & 1,17 & In load \\
\hline P5 & Marketing & 1.613 & 1.360 & 1,19 & In load \\
\hline P6 & Marketing & 1.724 & 1.360 & 1,27 & In load \\
\hline P7 & Marketing & 1.485 & 1.360 & 1,09 & In load \\
\hline P8 & Marketing & 1.356 & 1.360 & 1,00 & In load \\
\hline P9 & Marketing & 1.007 & 1.360 & 0,74 & Under load \\
\hline P10 & Marketing & 1.757 & 1.360 & 1,29 & Overload \\
\hline P11 & Marketing & 1.782 & 1.360 & 1,31 & Overload \\
\hline P12 & Marketing & 1.200 & 1.360 & 0,88 & Under load \\
\hline P13 & Marketing & 1.243 & 1.360 & 0,91 & Under load \\
\hline P14 & Marketing & 1.700 & 1.360 & 1,25 & In load \\
\hline P15 & Marketing & 1.920 & 1.360 & 1,41 & Overload \\
\hline \multirow[t]{2}{*}{ P16 } & Marketing & 1.798 & 1.360 & 1,32 & Overload \\
\hline & Total & 23.463 & 1.360 & 1.07 & In load \\
\hline
\end{tabular}

Based on the calculation of the workload of employees using the FTE method, it is known that there are 16 employees with an underload workload, an inload workload of 13 employees and an employee with an overloaded workload of 8 employees. Meanwhile, when viewed from each work division, there are divisions with normal workloads of 4 divisions, including HRD \& GA, Claims, Underwriting and Marketing divisions and 1 underload division, namely the finance division.

In accordance with the data above, the company can add employees to each division. However, as for other options besides adding employees, namely by providing overtime to employees and paying overtime wages because if the company adds employees to each division, the company must issue salaries for these additional employees, but if employees are given overtime and overtime wages then will save more costs incurred by the company.

\section{Analysis of Total Employee Needs}

Calculating the number of employee needs in each division using the formula for HR needs as follows:

$$
\text { Employee Needs }=\frac{\sum W P T}{\sum W K E} \times 1 \text { person }
$$

Table 2. Employee Needs

\begin{tabular}{|c|l|c|c|}
\hline No & \multicolumn{1}{|c|}{ Division } & Employee Needs (Persons) & Rounding \\
\hline 1 & HRD \& GA & 1.06 & 2 \\
\hline 2 & Underwriting & 8.21 & 9 \\
\hline 3 & Claim & 8.3 & 9 \\
\hline 4 & Finance & 3.53 & 4 \\
\hline 5 & Marketing & 17.18 & 18 \\
\hline \multicolumn{4}{|l|}{ Total } \\
\hline
\end{tabular}

It is known that the need for employees in this company is 42 people while the company only has 37 people.

\section{CONCLUSION}

1. Calculation of employee working time begins with calculating the employee's effective working days and hours. The result of the calculation is that the effective working day for a year is 226 days and the effective working time is 1,360 hours. Effective working days are Monday to Friday and working hours are from 08.00-17.00 WIB.

2. In summary, the use of time calculated by the Work Sampling method is known that the total time for productive activities is $78 \%$, unproductive activities are $11 \%$ and personal activities are $11 \%$. This means that in this company employees use their working time for productive activities.

3. From the calculation of the need for the number of employees, it is known that the HRD\&GA division requires 2 people, Underwriting requires 9 employees, Claims requires 9 employees and Finance requires 4 employees which is in accordance with the actual and Marketing Division requires 18 
employees. The Finance Division already has the appropriate number of employees calculated. Meanwhile, the number of needs for the Claim, Underwriting and HRD \& GA Divisions lacks 1 employee and the Marketing Division lacks 2 employees.

4. After measuring the workload with the Full Time Equivalent method, it can be seen that there are 16 employees with an underload workload, an inload workload of 13 employees and an employee with an overloaded workload of 8 employees.

\section{Acknowledgement: None}

\section{Conflict of Interest: None}

\section{Source of Funding: None}

\section{REFERENCES}

1. Anisa, H. N, \& Prastawa, H. (2019). Analisis Beban Kerja Pegawai dengan Metode Full Time Equivalent (FTE) (Studi Kasus pada PT. PLN (Persero) Distribusi

2. Aprilyanti, S. (2017). Pengaruh Usia dan Masa Kerja terhadap Produktivitas Kerja (Studi Kasus pada PT. OASIS Water International cabang Palembang). Jurnal Sistem dan Manajemen Industri. Volume 1. No 2.

3. Chizbiyah, W., Purnama, N., Witcahyo, E., Utami, S. \& Chalidyanto, D. (2020). The Analysis of Workload of Outpatient Officers Based on Health Workload Analysis Method. EurAsian Journal of BioSciences.

4. Dessler, G. (2020). Human Resource Management. 16th Edition. Pearson. United States of America.

5. Diniaty, D., Dev \& Febriadi, R. (2015). Analisis Beban Kerja dengan menggunakan Metode Work Sampling. Jurnal Teknik Industri. Volume 1. No 2.

6. Handoko, M. S. \& Sunardi. (2020). Perencanaan Pegawai Berbasis Beban Kerja dengan Metode Full Time Equivalent di Badan Pengelolaan Keuangan dan Pajak Daerah Kota XYZ. Jurnal Ilmiah Manajemen Industri dan Teknologi. Volume 1 No 2.

7. Hartono, W., \& Kusuma, M. (2020). Pengaruh Beban Kerja dan Disiplin Kerja terhadap Kinerja Pegawai (Pada Pt. Sembilan Pilar Utama). Jurnal Ilmiah Ekonomi dan Bisnis. Doi: https://doi.org/13.11114

8. Herdiansyah, Y.G. \& Aulawi, H. (2018). Analisis Beban Kerja untuk menentukan Jumlah Kebutuhan Tenaga Kerja Divisi Administrasi Umum di PT. Indonesia Power Unit PLTP Darajat. Jurnal Kalibrasi. ISSN: 2302-7320, Volume 16. No 2.

9. Kurniawan, H. S. (2020). Analisis Beban Kerja Pegawai PT XYZ Indonesia pada bagian Insulation menggunakan Metode Full Time Equivalent. STRING (Satuan Tulisan Riset dan Inovasi Teknologi). Volume 5. No 2.

10. Lestari, P \& Trisyulianti, E. (2018). Analisis Beban Kerja dan Kebutuhan Karyawan Direktorat Operasional Kantor Pusat PT Perkebunan Nusantara VIII. Jurnal Manajemen dan Organisasi (JMO). Volume 9. No 3.

11. Mondy, R.W., \& Martocchio. J. J. (2016). Human Resource Management. 14th Edition. Pearson. United States of America.

12. Muchransyah, M. H. Q. \& Rahmawati, S. (2016). Analisis Beban Kerja dan Kebutuhan Pegawai di Pusat Perpusyakaan dan Penyebaran Teknologi Pertanian (PUSTAKA). Jurnal Manajemen dan Organisasi. Volume 7. No 2.

13. Nasution, H. (2005). Proses Pengelolaan Sumber Daya Manusia. Cetakan 1, Usu Press. Medan.

14. Nasution, H. (2016). Merencanakan Riset. Cetakan 1, Usu Press. Medan.

15. Omar, M. K., Aluwi. A. H., Fauzi, M.W.M., \& Hairpuddin, N. F. (2020). Work Stress, Workload, Work-Life Balance, and Intention to Leave Among Employees of an Insurance Company in Malaysia. International Journal of Business, Economic and Law. Volume 21. No 2.

16. Pranoto, L. H. \& Retnowati. (2019). Analisis Beban Kerja Sumber Daya Manusia. Cetakan 6, PT Gramedia Pustaka Utama. Jakarta.

17. Rafli, A. A., Nasution, H., A \& Absah, Y. (2020). Analysis of Total Employee Needs Based on Measurement of Workloads at PT. Garuda Indonesia Brach Office Medan. International Journal of Research and Review. Volume 7 No 10.

18. Sari, W. O. S. R., Sakka, A., \& Paridah. (2017). Analisis Beban Kerja dengan 
Metode Full Time Equivalent FTE pada Dokter Umum di Rumah Sakit Umum Bahteramas provinsi Sulawesi Tenggara Tahun 2017. Jurnal Ilmiah Mahasiswa Kesehatan Masyarakat. Volume 2. No 6.

19. Sinulingga, S. (2018). Metode Penelitian. Edisi 3, Usu Press. Medan.

20. Sugiyono. (2016). Metode Penelitian Kuantitatif, Kualitatif, dan R\&D. Cetakan 23. Alfabeta: Bandung.

21. Tarwaka., Bakri, S. H., \& Sudiajeng, L. (2004). Ergomomi untuk Keselamatan, Kesehatan Kerja dan Produktivitas. Edisi 1. Cetakan 1. UNIBA PRESS: Surakarta.

22. Taufiq, M., \& Fitri, S. (2018). Analisis Performa dan Kebutuhan Informasi untuk Meningkatkan Kinerja Sistem Informasi Penerimaan Mahasiswa Baru di Universitas Muhammadiyah Tasikmalaya. Jurnal Produktif. Volume 2. No 1.

23. Widiastuti, R., Nurhayati, E., \& Sari, E. N.I. (2019). Analisis Beban Kerja Fisik dan Mental Petugas Cleaning Service menggunakan Metode Work Sampling dan Nasa-TLX (Studi Kasus: UPT Stasiun Besar Lempuyangan). Jurnal Teknologi Technoscientia. Volume 12. No 1.

24. Wardanis, D., T. (2018). Analisis Beban Kerja Tenaga Rekam Medis Rumah Sakit Bedah Surabaya Menggunakan Metode FTE. Jurnal Administrasi Kesehatan Indonesia. Volume 6. No 1.
25. Wignjosoebroto, S. (2006). Ergonomi, Studi Gerak dan Waktu (Teknik Analisis untuk Peningkatan Produktivitas Kerja). Edisi Pertama. Cetakan 4, PT Guna Widya. Jakarta.

26. Yasin, M., \& Priyono. J. (2016). Analisis Faktor Usia, Gaji dan Beban Tanggungan terhadap Produksi Home Industri Sepatu di Sidoarjo (Studi Kasis di Kecamatan Krian). Jurnal Ekonomi dan Bisnis. Volume 1. No 1.

27. Yasmin, Z. A, \& Ariyanti. S. (2018). Analisis Beban Kerja pada Maintenance BD-Check dengan Metode Full Time Equivalent. Jurnal Ilmiah Teknik Industri. Volume 6 No 1.

28. Yusuf, Anfas, \& Sudarwo. R. (2017). Analisis Beban Kerja terhadap Kebutuhan Pegawai Administrasi dalam Menjamin Optimalisasi Operasional Akademik. Jurnal Organisasi dan Manajemen. Volume 13. No 1.

How to cite this article: Aninda S, Nasution H, Maas LT. Allocation of the number of employees based on workload at PT Asuransi Central Asia Medan branch. International Journal of Research and Review. 2021; 8(11): 148-154. DOI: https://doi.org/10.52403/ijrr. 20211120 